\title{
Selectivity in cyclopropanations and 1,3-cycloadditions in transition metal-catalyzed decompositions of 2-diazocyclohexane-1,3-diones and the corresponding phenyliodonium ylides
}

\author{
Paul Müller,* Yves F. Allenbach, Maria Ferri, and Gérald Bernardinelli \\ Department of Organic Chemistry, University of Geneva, 30, Quai Ernest Ansermet, CH-1211 \\ Geneva 4 Switzerland \\ E-mail:paul.muller@chiorg.unige.ch
}

Dedicated to Prof. E. A. McKervey on his $65^{\text {th }}$ birthday
(received 28 Feb 03; accepted 14 Apr 03; published on the web 30 Apr 03)

\begin{abstract}
The cyclopropanation of olefins with 2-diazodimedone $\mathbf{1 a}$ and the corresponding phenyliodonium ylide $\mathbf{1 b}$ in the presence of selected chiral $\mathrm{Cu}(\mathrm{I})$ - and $\mathrm{Rh}(\mathrm{II})$-catalysts proceeds without significant enantioselectivity. Contrary to previous reports in the literature, the cyclopropanation of styrene with $\mathbf{1 a}$ in the presence of $\left[\mathrm{Cu}\{(+) \text {-facam }\}_{2}\right]$ is not enantioselective. While the transition metal catalyzed 1,3-dipolar cycloaddition of 2-diazodimedone (1a) to furan and dihydrofuran is equally non-selective, the introduction of heteroatoms and/or unsaturation in the carbene precursor results in slightly enhanced enantioselectivity.
\end{abstract}

Keywords: Transition metal-catalysts, carbene transfer, enantioselectivity, cyclopropanation, 1,3-dipolar cycloaddition, 2-diazo-1,3-diones, phenyliodonium ylide

\section{Introduction}

The decomposition of diazo compounds in the presence of chiral, non-racemic transition metalcatalysts affords metallocarbenes capable of asymmetric carbene transfer. ${ }^{1}$ Impressive enantioselectivities have been reported for inter- and/or intramolecular cyclopropanations and $\mathrm{CH}$-insertions with diazoacetates, diazoacetamides, and phenyl- or vinyl diazoacetate esters. ${ }^{2}$ In addition, diazo ketones or ketoesters carrying electron-attracting substituents, such as ethyl diazoacetoacetate $^{3}$ ethyl diazopyruvate ${ }^{4}$ or 2-diazocyclohexane-1,3-dione ${ }^{5}$ may undergo formal 1,3-cycloaddition to polar or polarizable olefins. Enantioselective cycloadditions of 2diazodimedone (1a) and 2-diazocyclohexane-1,3-dione (2a) to furan and dihydrofuran in the presence of chiral $\mathrm{Rh}(\mathrm{II})$-catalysts have been reported, with ee's in the range of 50 to $95 \%$ according to the catalysts used (Scheme 1). ${ }^{6,7}$ We have recently re-examined these reactions but 
were unable to reproduce the reported results under the conditions described by the authors. ${ }^{8} \mathrm{~A}$ considerable number of structurally different catalysts was screened for the cycloadditions with $\mathbf{1 a}$ and $\mathbf{2 a}$, and the corresponding ylides $\mathbf{1} \mathbf{b}$, and $\mathbf{2} \mathbf{b}$, but no enantioselective cycloadditions could be realized. These negative results are even more striking in the light of our recent observation, that enantioselective Rh(II)-catalyzed carbene transfer with the ylide $\mathbf{3 b}$ derived from Meldrum's acid proceed with ee's of up to 65\%. The behaviour of $\mathbf{3 b}$ is not directly comparable to that of $\mathbf{1}$ or $\mathbf{2}$, since the metallocarbene derived from $\mathbf{3 b}$ participates in cyclopropanations, while $\mathbf{1}$ and $\mathbf{2}$ typically afford products of 1,3-dipolar cycloaddition. Note that in the particular case of $\mathbf{3}$ reactions were carried out with the ylide $\mathbf{3 b}$, rather than the diazo compound $\mathbf{3 a}$, because the latter is quite resistant towards diazo decomposition and requires temperatures in the range of $80^{\circ} \mathrm{C}$, while reactions with the ylide $\mathbf{3 b}$ may be conveniently carried out at room temperature. ${ }^{9}$

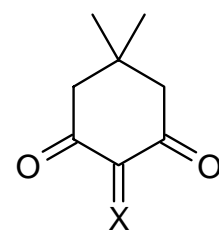

$1 \mathrm{a} X=\mathrm{N}_{2}$

1b $X=I P h$ 1c $X=\mathrm{H}_{2}$

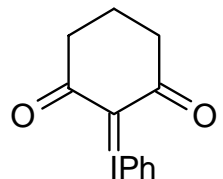

$2 \mathrm{a} X=\mathrm{N}_{2}$

2b $X=I P h$

2c $X=H_{2}$<smiles>[X]C1=C(C(=O)OC)OC(C)(C)OC1=O</smiles>

3a $X=N_{2}$

3b $X=I P h$

3c $X=\mathrm{H}_{2}$

\section{Scheme 1}

The absence of enantioselectivity in the cycloadditions of $\mathbf{1 a}$ and $\mathbf{1 b}$ to furans may be attributed to various causes such as formation of a free ylide between the carbene and the oxygen atom of the furan, a possibly inherent low enantioselectivity of dipolar cycloadditions of metallocarbenes, or the poor selectivity of the carbene itself. At first glance, this latter point appeared unlikely, since enantioselective carbene transfer with 1a has been reported: Matlin et al. observed enantioselective cyclopropanation of styrene with 1a in the presence of chiral $\mathrm{Cu}(\mathrm{I})$ catalysts at elevated temperatures in $21-48 \%$ yield and with $73.3-100 \%$ ee. The readily avaliable $\left[\mathrm{Cu}\{(+) \text {-facam }\}_{2}\right]$ produced the cyclopropane in $36 \%$ yield and with $91.7 \%$ ee. ${ }^{10}$ However, details of the procedure have not been published, and the reported results have met some scepticisme. $^{11}$<smiles>[X]C1C(=O)CC(C)(C)OC1=O</smiles>

$4 \mathrm{a} X=\mathrm{N}_{2}$ $\mathbf{4 b} X=\mathrm{IPh}$ 4c $\mathrm{X}=\mathrm{H}_{2}$<smiles></smiles>

$5 \mathbf{a} X=\mathrm{N}_{2}$

5b $X=I P h$ 5c $X=\mathrm{H}_{2}$<smiles></smiles>

$6 \mathbf{a} X=\mathrm{N}_{2}$

6b $X=I P h$

6c $X=\mathrm{H}_{2}$<smiles>[X]C1C(=O)C=C(C)OC1=O</smiles>

$7 \mathrm{a} X=\mathrm{N}_{2}$

7b $X=I P h$

7c $X=\mathrm{H}_{2}$<smiles>[X]C1C(=O)N(C)C(=O)N(C)C1=O</smiles>

$8 \mathbf{a} X=N_{2}$

8b $X=I P h$

$8 c X=\mathrm{H}_{2}$ 


\section{Scheme 2}

In view of our difficulties with the reproduction of the enantioselectivity of the cycloadditions of $\mathbf{1 a}$ and $\mathbf{1 b}$ to furans, we have repeated the cyclopropanation of styrene with $\mathbf{1 a}$ in the presence of $\left[\mathrm{Cu}\{(+) \text {-facam }\}_{2}\right]$, and we have investigated the cyclopropanation of terminal olefins with Rh(II)-catalysts. In addition, we have examined the influence of heteroatoms on the selectivity of the carbenes derived from the corresponding ylides $\mathbf{4 b - 8 b}$ (Scheme 2) in the cycloaddition to furan and 2,3-dihydrofuran. The ylides were preferred over the corresponding diazo compounds owing to their generally higher reactivity in transition metal-catalyzed carbene transfer reactions. ${ }^{8}$

\section{Results and Discussion}

\section{Cyclopropanation of styrene and apolar terminal olefins}

The conditions of Matlin et al. ${ }^{10}$ for cycloproanation of styrene consist in heating styrene neat or in toluene to reflux in the presence of $\mathbf{1 a}$ and the appropriate $\mathrm{Cu}$-catalyst. In our hands, these reaction conditions resulted in complete polymerization of styrene, and no cyclopropane could be isolated. Cyclopropanation did occur, however, in 53\% yield with the phenyliodonium ylide $\mathbf{1 b}$ and $\left[\mathrm{Cu}_{2}\{(+) \text {-facam }\}_{4}\right]^{12}$ but the cyclopropane (9a) was racemic (Scheme 3 and Table 1).
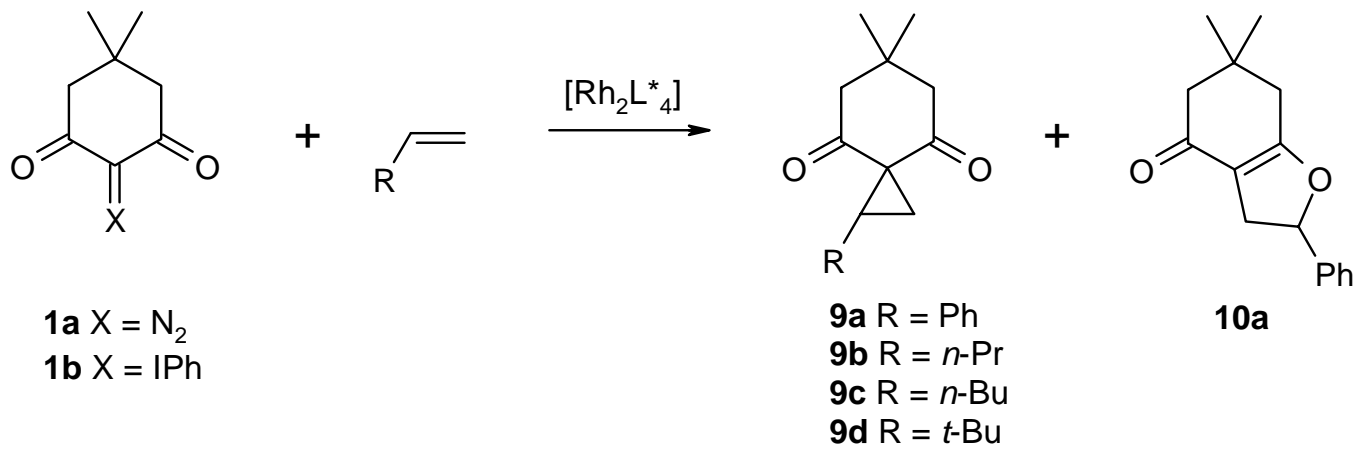

\section{Scheme 3}

When the cyclopropanation of styrene was carried out with $\left[\mathrm{Rh}_{2}(\mathrm{OAc})_{4}\right]$ or $\left[\mathrm{Rh}_{2}\{(S)-\mathrm{nttl}\}_{4}\right]$, the yield of cyclopropane 9a varied in the range of 35-49\%, and a formal cycloadduct 10a was isolated in 22-35\% yield as secondary product. The structure of 10a was established by comparison of the spectral data with those of the known product resulting from reaction of 2,2dibromodimedone with styrene in the presence of copper. ${ }^{13}$ The origin of the cycloadduct is not clear. The stability of the cyclopropanes 9a and 9c under the conditions of the reaction was verified $\left(\left[\mathrm{Rh}_{2}(\mathrm{OAc})_{4}\right]\right.$ in trifluorotoluene at r.t. for $\left.72 \mathrm{~h}\right)$, and it was found that the cyclopropanes do not rearrange to the respective cycloadducts. Thus styrene may react with $\mathbf{1 b}$ via two 
competing pathways, namely via cyclopropanation or formal cycloaddition. The mechanism of the cycloaddition is not established, and may be concerted or stepwise. It is interesting to note, in this context, that the related cycloaddition of 2,2-dibromo-dimedone with cis- and trans- $\beta$ methylstyrene in the presence of copper is not stereospecific and, therefore, must proceed stepwise. $^{13}$

Table 1. Cyclopropanation and Cycloaddition of terminal olefins with 2-diazo-dimedone (1a) and phenyliodonium ylide $\mathbf{1 b}^{\text {a) }}$

\begin{tabular}{|c|c|c|c|c|c|c|}
\hline Cpd & $\mathrm{X}$ & $\mathrm{R}$ & Catalyst/Solvent & $\begin{array}{l}\text { Cyclopr. } \\
\text { Yield (\%) }\end{array}$ & $\begin{array}{c}\text { ee } \\
(\%)\end{array}$ & $\begin{array}{c}\text { Adduct } \\
(\%)\end{array}$ \\
\hline 1a & $\mathrm{N}_{2}$ & $\mathrm{Ph}$ & {$\left[\mathrm{Cu}\{(+) \text { facam }\}_{2}\right] /$ styrene $^{(\mathrm{b})}$} & 9a 36 & 91.7 & 0 \\
\hline 1a & $\mathrm{N}_{2}$ & $\mathrm{Ph}$ & {$\left[\mathrm{Cu}\{(+) \text { facam }\}_{2}\right] /$ styrene $^{(\mathrm{c})}$} & 9a 0 & - & 0 \\
\hline 1b & $\mathrm{IPh}$ & $\mathrm{Ph}$ & {$\left[\mathrm{Cu}\left\{(+) \mathrm{facam}_{2}\right] / \mathrm{PhCH}_{3}\right.$} & 9a 53 & 0 & 0 \\
\hline 1a & $\mathrm{N}_{2}$ & $\mathrm{Ph}$ & {$\left[\mathrm{Rh}_{2}(\mathrm{OAc})_{4}\right] /$ styrene } & 9a 49 & - & 10a 22 \\
\hline 1a & $\mathrm{N}_{2}$ & $\mathrm{Ph}$ & {$\left[\mathrm{Rh}_{2}\{(S)-\mathrm{nttl}\}_{4}\right] / \mathrm{PhCH}_{3}$} & 9a 35 & 0 & 10a 35 \\
\hline 1b & $\mathrm{IPh}$ & $\mathrm{Ph}$ & {$\left[\mathrm{Rh}_{2}(\mathrm{OAc})_{4}\right] /$ styrene } & $9 a$ & - & 10a 30 \\
\hline 1b & $\mathrm{IPh}$ & $\mathrm{Ph}$ & {$\left[\mathrm{Rh}_{2}\{(S)-n t t l\}_{4}\right]$} & 9a 37 & 0 & 10a 34 \\
\hline 1a & $\mathrm{N}_{2}$ & $n-\operatorname{Pr}$ & {$\left[\mathrm{Rh}_{2}(\mathrm{OAc})_{4}\right] / \mathrm{PhCF}_{3}$} & 9b 31 & - & 0 \\
\hline 1a & $\mathrm{N}_{2}$ & $n-\mathrm{Bu}$ & {$\left[\mathrm{Rh}_{2}(\mathrm{OAc})_{4}\right] / \mathrm{PhCF}_{3}$} & 9c 34 & - & 0 \\
\hline 1b & $\mathrm{IPh}$ & $n-\mathrm{Bu}$ & {$\left[\mathrm{Rh}_{2}(\mathrm{OAc})_{4}\right] / \mathrm{PhCH}_{3}$} & 9c 18 & - & 0 \\
\hline 1a & $\mathrm{N}_{2}$ & $n-\mathrm{Bu}$ & {$\left[\mathrm{Rh}_{2}\{(R)-\mathrm{ntvl}\}_{4}\right] /$ hexene } & 9d 29 & 8 & 0 \\
\hline 1a & $\mathrm{N}_{2}$ & $t-\mathrm{Bu}$ & {$\left[\mathrm{Rh}_{2}(\mathrm{OAc})_{4}\right] / \mathrm{PhCF}_{3}$} & 9d 25 & - & 0 \\
\hline 1a & $\mathrm{N}_{2}$ & $t-\mathrm{Bu}$ & {$\left[\mathrm{Rh}_{2}\{(S)-\mathrm{nttl}\}_{4}\right] / \mathrm{PhCF}_{3}$} & 9d 24 & 16 & 0 \\
\hline
\end{tabular}

(a) Conditions: At $25{ }^{\circ} \mathrm{C}$, with 5\% of catalyst, 10 - 15-fold excess of olefin, unless indicated otherwise. ${ }^{(b)}$ At reflux, ref. ${ }^{10 \text { (c) }}$ At reflux, this work.

The reaction of $\mathbf{1 b}$ in the presence of $\left[\mathrm{Rh}_{2}\{(S)-\mathrm{nttl}\}_{4}\right]$ resulted only in racemic cyclopropane 9a and racemic cycloadduct 10a. This compares unfavorably with the ee of $37 \%$ resulting from the cyclopropantion of styrene with the ylide $\mathbf{3 b}$ using the same catalyst. Simple terminal olefins reacted also with 2-diazodimedone (1a) or the corresponding phenyliodonium ylide (1b), respectively, in the presence of $\left[\mathrm{Rh}_{2}(\mathrm{OAc})_{4}\right]$ to afford cyclopropanes $\mathbf{9 b}-\mathbf{d}$ in moderate yield (Table 1). However, no cycloadducts of type $\mathbf{1 0}$ were observed. Thus it appears that cycloaddition is restricted to polar or polarizable olefins with Rh(II)-catalysts. In the presence of $\left[\mathrm{Rh}_{2}\{(\mathrm{~S})-\mathrm{nttl}\}_{4}\right]$ the reactions proceeded with a small, but reproducible induction. It is interesting to note that the most hindered olefin ( $t$-butylethylene) exhibited the highest ee in the series with $16 \%$. No attempt was made at this point to improve the enantioselectivity by screening other catalysts. 


\section{Cycloaddition of 2,2-dimethyl-5-diazo-1-oxacyclohexane-4,6-dione (4a) and phenyliodonium ylide $4 \mathrm{~b}$ to furan and dihydrofuran}

The carbene precursor $\mathbf{4 a}, \mathbf{b}$ reacted in neat furan or 2,3-dihydrofuran, respectively, or in inert solvents such as fluorobenzene, trifluorotoluene or toluene in the presence of $\left[\mathrm{Rh}_{2}(\mathrm{OAc})_{2}\right]$ to afford the adducts 11 and 12, respectively (Scheme 4). The reaction was fully regioselective, with the addition involving the carbonyl group of the ketone rather than that of the ester function, and the regioisomers 14 and 15, respectively, were not detected in the reaction mixture. The structure of the adducts is consistent with the higher polar character of the ketone group over that of the ester function. It was tentatively assigned for $\mathbf{1 2}$ on the grounds of ${ }^{13} \mathrm{C}$ NMR shift calculations using SpecTool. ${ }^{14}$ The signals attributed to C(3b), C(4) and C(7a) of 12 appear at 101.6, 170.8 and $164.0 \mathrm{ppm}$, in good agreement with the calculated values of 98.1, 165.0 and $161.1 \mathrm{ppm}$. The chemical shifts of the isomer $\mathbf{1 5}$ are calculated at 78.6, 197.6, and $172.9 \mathrm{ppm}$. The X-ray structure of $\mathbf{1 2}$ confirms the tentative assignement. The structure of the addition product $\mathbf{1 1}$ resulting from reaction with furan was assigned by analogy. Compound $\mathbf{1 1}$ could not be fully characterized owing to its decomposition during work up to a mixture of two aldehydes of as yet unknown structure. A secondary product resulting from rearrangement of the ylide $\mathbf{4 b}$ was observed in some reactions, but could not be fully identified owing to decomposition under the reaction conditions. The structure of $\mathbf{1 3}$ is tentatively assigned on the grounds of analogous rearrangements observed upon heating of phenyliodonium ylides. ${ }^{15,16}$ The yields for the cycloadditions are acceptable for dihydrofuran (35-78\%), but are poor for furan, which is less reactive.

The enantioselectivity of the reaction was tested with several $\mathrm{Rh}(\mathrm{II})$-catalysts. In general, enantioselectivity was disappointingly low. For furan, the best result (22\%) was achieved with $\left[\mathrm{Rh}_{2}\{(S) \text {-pttl }\}_{4}\right]$, and for 2,3-dihydrofuran (26\%) with $\left[\mathrm{Rh}_{2}\{(S) \text {-nttl }\}_{4}\right]$. Although this is not high, it is still much better than in the cycloaddition of diazodimedone.

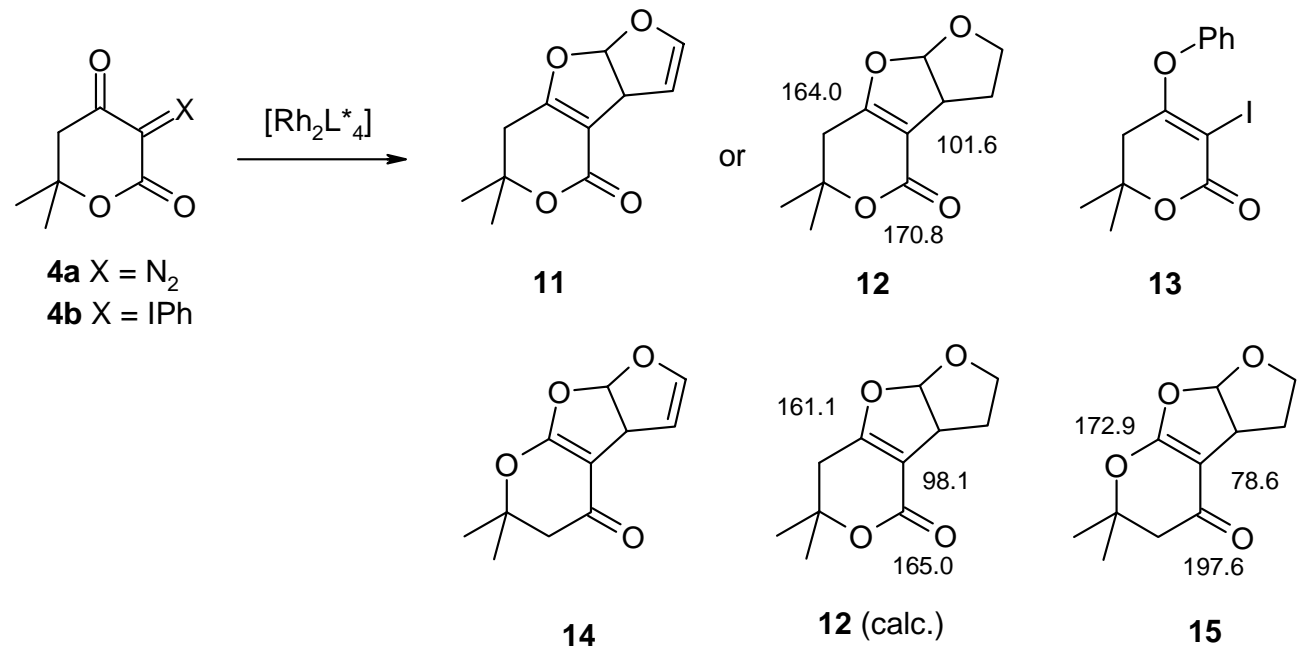

\section{Scheme 4}




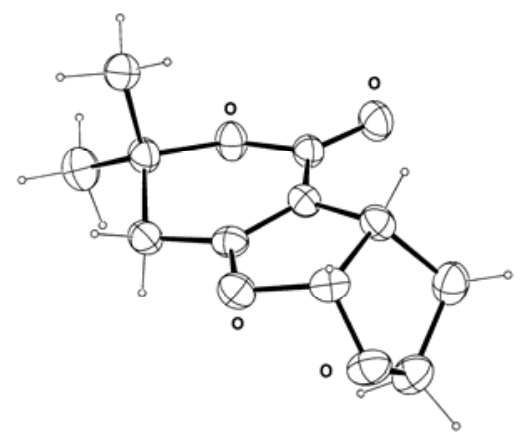

Figure 1. X-Ray crystal structure of 12. Ellipsoids are represented with 40\% probability level.

Table 2. Cycloaddition of 4a,b to Furan and Dihydrofuran

\begin{tabular}{|c|c|c|c|c|c|c|}
\hline Cpd & $X=$ & Dipolarophile & Catalyst & Solvent & Adduct & ee \\
\hline $4 a$ & $\mathrm{~N}_{2}$ & Furan $^{(a)}$ & {$\left[\mathrm{Rh}_{2}(\mathrm{OAc})_{4}\right]$} & $\mathrm{PhCF}_{3}$ & 11 12\% & - \\
\hline $4 b$ & $\mathrm{IPh}$ & Furan $^{(a)}$ & {$\left[\mathrm{Rh}_{2}(\mathrm{OAc})_{4}\right]$} & $\mathrm{PhCH}_{3}$ & $1118 \%$ & -- \\
\hline $4 a$ & $\mathrm{~N}_{2}$ & Furan $^{(a)}$ & {$\left[\mathrm{Rh}_{2}\{(S)-\mathrm{pttl}\}_{4}\right]$} & $\mathrm{PhCF}_{3}$ & $1117 \%$ & $22 \%$ \\
\hline $4 b$ & $\mathrm{IPh}$ & Dihydrofuran ${ }^{(b)}$ & {$\left[\mathrm{Rh}_{2}\{(S)-\mathrm{nttl}\}_{4}\right]$} & $\mathrm{PhCF}_{3}$ & $1235 \%$ & $24 \%$ \\
\hline $4 b$ & $\mathrm{IPh}$ & Dihydrofuran $^{(b)}$ & {$\left[\mathrm{Rh}_{2}\{(S)-\mathrm{nttl}\}_{4}\right]$} & $\mathrm{PhCH}_{3}$ & $1271 \%$ & $26 \%$ \\
\hline 4b & $\mathrm{IPh}$ & Dihydrofuran ${ }^{(\mathrm{b})}$ & {$\left[\mathrm{Rh}_{2}\{(S)-\text { ptpa }\}_{4}\right]$} & $\mathrm{CH}_{2} \mathrm{Cl}_{2}$ & $1278 \%$ & $1 \%$ \\
\hline $4 b$ & $\mathrm{IPh}$ & Dihydrofuran ${ }^{(b)}$ & {$\left[\mathrm{Rh}_{2}\{(S)-\operatorname{dosp}\}_{4}\right]$} & $\mathrm{PhCH}_{3}$ & $1247 \%$ & $4 \%$ \\
\hline $4 b$ & $\mathrm{IPh}$ & Dihydrofuran $^{(b)}$ & {$\left[\mathrm{Rh}_{2}\{(S) \text {-campha }\}_{4}\right]$} & $\mathrm{PhCH}_{3}$ & $1263 \%$ & $0 \%$ \\
\hline $4 b$ & $\mathrm{IPh}$ & Dihydrofuran $^{(b)}$ & {$\left[\mathrm{Rh}_{2}\{(2 S)-\text { mepy }\}_{4}\right]$} & $\mathrm{PhCH}_{3}$ & $1252 \%$ & $0 \%$ \\
\hline $4 b$ & $\mathrm{IPh}$ & Dihydrofuran $^{(b)}$ & {$\left[\mathrm{Rh}_{2}\{(S)-\mathrm{bnp}\}_{4}\right]$} & $\mathrm{PhCF}_{3}$ & $1244 \%$ & $0 \%$ \\
\hline
\end{tabular}

(a) Conditions: $0.50 \mathrm{mmol}$ of $\mathbf{4 a , b} 3.0 \mathrm{~mL}$ of furan, $6.0 \mathrm{~mL}$ of $\mathrm{PhCF}_{3}, 5 \mathrm{~mol} \%$ of catalyst, $12 \mathrm{~h}$ reflux. ${ }^{(b)}$ : $0.5 \mathrm{mmol}$ of $\mathbf{4 b}$, 15 eq. of dihydrofuran in $8.0 \mathrm{~mL}$ of solvent, $5 \mathrm{~mol} \%$ of catalyst, $12 \mathrm{~h}$ reflux.

\section{Cycloaddition with the ylide derived from chromane-2,4-dione (5b)}

The decomposition of the ylide $\mathbf{5 b}$ required heating to $60{ }^{\circ} \mathrm{C}$, and at this temperature $\mathbf{5 b}$ rearranged partially to $\mathbf{1 8}$. The cycloadditions to furan proceeded to $\mathbf{1 6}$ in yields of 6-36\%, while those with dihydrofuran were more efficient and furnished $\mathbf{1 7}$ in up to $72 \%$ yield. In view of the poor yields of 16, the cycloadditions with furan were not further investigated. However, it was noted that in the presence of the less reactive substrate, the yield of rearrangement product $\mathbf{1 8}$ increased, and that the rearrangement was accelerated by the catalyst. The rearrangement of phenyliodonium ylides to iodoethers is believed to be intramolecular. ${ }^{14}$ Since the rate of ylide decomposition is independent of the substrate present, the lower yield of cycloadduct with the 
less reactive substrate (furan) suggests, that formation of the metallocarbene from the ylide should be reversible. ${ }^{17}$

The cycloaddition is entirely regioselective. As before, only the carbonyl group of the ketone is involved in the reaction. The structure of the adduct $\mathbf{1 7}$ was confirmed by X-ray structure analysis. The enantioselectivities culminated at $31 \%$ ee for $\mathbf{1 6}$ and at $12 \%$ ee for $\mathbf{1 7}$.

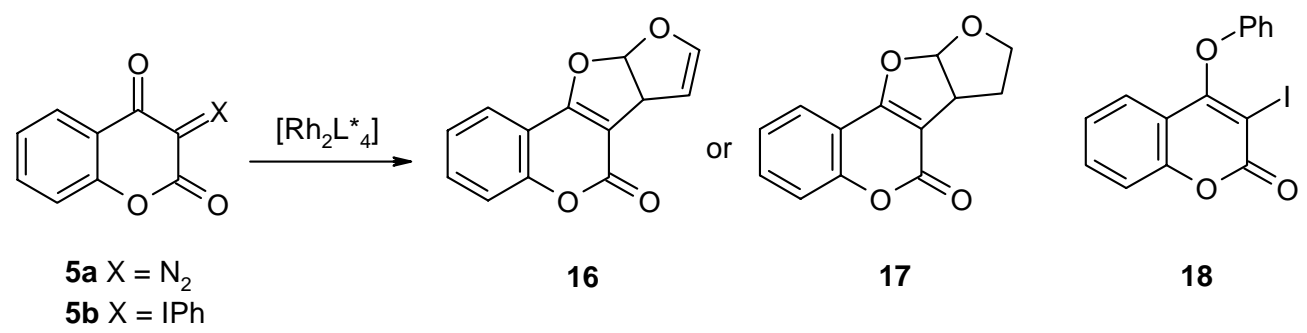

\section{Scheme 5}

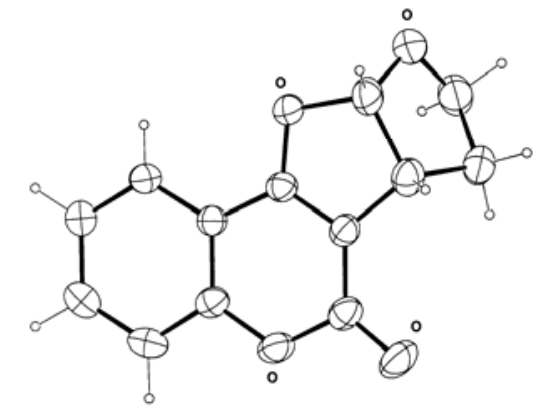

Figure 2. X-Ray crystal structure of $\mathbf{1 7}$. Ellipsoids are represented with $40 \%$ probability level.

Table 3. Cycloaddition of ylide $\mathbf{5 b}$ with furan and dihydrofuran ${ }^{(a)}$

\begin{tabular}{lllll}
\hline Dipolarophile & Catalyst & Solvent & Adduct (\%) & ee (\%) \\
\hline Furan & {$\left[\mathrm{Rh}_{2}(\mathrm{Oac})_{4}\right]$} & $\mathrm{Neat}$ & $\mathbf{1 5}$ & -- \\
Furan & {$\left[\mathrm{Rh}_{2}\{(S)-\mathrm{pttl}\}_{4}\right]$} & $\mathrm{Neat}$ & $\mathbf{1 5} 36$ & 18 \\
Furan & {$\left[\mathrm{Rh}_{2}\{(S)-\mathrm{pttl}\}_{4}\right]$} & $\mathrm{PhCH}_{3}$ & $\mathbf{1 5} 06$ & 17 \\
Furan & {$\left[\mathrm{Rh}_{2}\{(S)-\mathrm{pttl}\}_{4}\right]$} & $\mathrm{CH}_{2} \mathrm{Cl}_{2}$ & $\mathbf{1 5} 06$ & 10 \\
Furan & {$\left[\mathrm{Rh}_{2}\{(S)-\mathrm{nttl}\}_{4}\right]$} & $\mathrm{PhCH}_{3}$ & $\mathbf{1 5} 08$ & 31 \\
Furan & {$\left[\mathrm{Rh}_{2}\{(S)-\mathrm{tsin}\}_{4}\right]$} & $\mathrm{PhCH}_{3}$ & $\mathbf{1 5} 15$ & 0 \\
Dihydrofuran & {$\left[\mathrm{Rh}_{2}(\mathrm{Oac})_{4}\right]$} & $\mathrm{PhCH}_{3}$ & $\mathbf{1 6} 57$ & -- \\
Dihydrofuran & {$\left[\mathrm{Rh}_{2}\{(S)-\mathrm{nttl}\}_{4}\right]$} & $\mathrm{PhCH}_{3}$ & $\mathbf{1 6} 72$ & 10 \\
Dihydrofuran & {$\left[\mathrm{Rh}_{2}\{(S)-\mathrm{pttl}\}_{4}\right]$} & $\mathrm{PhCH}_{3}$ & $\mathbf{1 6} 56$ & 12 \\
Dihydrofuran & {$\left[\mathrm{Rh}_{2}\{(5 S)-\mathrm{mepy}\}_{4}\right]$} & $\mathrm{PhCH}_{3}$ & $\mathbf{1 6} 22$ & 3 \\
Dihydrofuran & {$\left[\mathrm{Rh}_{2}\{(S)-\mathrm{tsop}\}_{4}\right]$} & $\mathrm{PhCH}_{3}$ & $\mathbf{1 6} 41$ & 0 \\
Dihydrofuran & {$\left[\mathrm{Rh}_{2}\{(S)-\mathrm{nbmatl}\}_{4}\right]$} & $\mathrm{PhCH}_{3}$ & $\mathbf{1 6} 36$ & 7 \\
\hline Dihydrofuran & {$\left[\mathrm{Rh}_{2}\{(S)-\mathrm{tbsin}\}_{4}\right]$} & $\mathrm{PhCH}_{3}$ & $\mathbf{1 6} 24$ & 0 \\
\hline
\end{tabular}




\begin{tabular}{|c|c|c|c|c|}
\hline Dihydrofuran & {$\left[\mathrm{Rh}_{2}\{(S) \text {-tbsop }\}_{4}\right]$} & $\mathrm{PhCH}_{3}$ & 1642 & 0 \\
\hline Dihydrofuran & {$\left[\mathrm{Rh}_{2}\{(S)-\operatorname{dosp}\}_{4}\right]$} & $\mathrm{PhCH}_{3}$ & 1646 & 0 \\
\hline
\end{tabular}

(a) Conditions: At $60{ }^{\circ} \mathrm{C}$, with $5 \%$ of catalyst.

\section{Cycloadditions with ylides (6b-8b)}

The decomposition of the ylides $\mathbf{6 b - 8 b}$ with $\mathrm{Rh}(\mathrm{II})$-catalysts afforded no characterizable products. This is surprising in the case of $\mathbf{6 a}$, because the corresponding diazo derivative $\mathbf{6 a}$ adds normally to olefins. ${ }^{18}$ The diazo analogue $\mathbf{7 a}$ of ylide $\mathbf{7 b}$ is not known in the literature; and attempts towards its preparation were not successful. In the case of $\mathbf{8 a}, \mathbf{b}$ both the diazo derivative and the ylide are too stable and may not be decomposed under normal conditions.

\section{Discussion}

We note that 2-diazodimedone (1a) and the ylide $\mathbf{1 b}$ exhibit very poor enantioselectivity in cyclopropanations of terminal olefins. As reported elsewhere, the same is true for cycloadditions to furans. While in the case of the cycloadditions to furans, the hypothesis of formation of a free ylide between carbene and substrate provides a plausible explanantion for the absence of enantioselectivity, this argument cannot be invoked in the cyclopropanation of simple olefins. Introduction of oxygen atoms in the ring of 1a results in a more selective carbene. Typically, the cyclopropanation of pentene and styrene proceed with ee's of 59 and 37\%, respectively with $\left[\mathrm{Rh}_{2}\{(S) \text {-nttl }\}_{4}\right]$, with the ylide derived from Meldrum's acid (3b). ${ }^{9}$ A similar trend, although much less pronounced, may be seen in the cycloaddition to dihydrofuran, where the enantioselectivity reaches $26 \%$ with $\mathbf{4 b}$ and $31 \%$ with $5 \mathbf{b}$ when $\left[\mathrm{Rh}_{2}\{(S)-n t t l\}_{4}\right]$ is used as catalyst. The effect of a second oxygen atom on the cycloaddition could not be examined because $3 \mathbf{b}$ does not undergo such reactions.

A tentative explanation for the low enantioselectivity of the diazodimedone (1a), or the corresponding phenyliodonium ylide $\mathbf{1 b}$ may be advanced on the grounds of the investigations of Davies. ${ }^{19}$ It was found that diazo esters carrying stabilizing substituents such as phenyl or vinyl groups, exhibit significantly higher $\rho$-values in the cyclopropanation of substituted styrenes than the unsubstituted diazoacetate esters. A higher $\rho$-value implies higher selectivity, owing to a transition state occurring later on the reaction coordinate. Interestingly, the more stabilized carbenes exhibit also higher enantioselectivities. Applying the same argument to carbenes derived from 1a,b, the absence of selectivity may be attributed to their higher reactivity in comparsion, for example, to the carbene derived from 3a,b, where the oxygen atoms provide some stabilization. The carbene derived from $\mathbf{4}$ and $\mathbf{5}$ are intermediate between these two, and exhibit intermediate enantioselectivity. This argument is consistent with the generally lower enantioselectivity for reactions involving diazo ketones ${ }^{20}$ in comparison to diazo esters or diazo amides, although a few enantioselective catalysts for diazo ketones have been reported. ${ }^{21,22}$

\section{Experimental Section}


General: See ref. ${ }^{23}$<smiles>CC1(C)C2C=CC1C(C(=O)C(F)(F)F)C2=O</smiles>

$\left[\mathrm{Cu}\{(+)-\text { facam }\}_{2}\right]$<smiles>CC12CCC(C(=O)O)(C(=O)O1)C2(C)C</smiles>

$\left.\mathrm{Rh}_{2}\{(R) \text {-campha }\}_{4}\right]$<smiles>CC(=O)[C@H]1CCC(=O)N1</smiles>

$\left[\mathrm{Rh}_{2}\{(5 S)-\text { mepy })_{4}\right]$

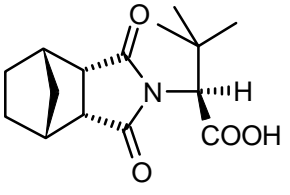

$\left[\mathrm{Rh}_{2}\{(\mathrm{~S})-\mathrm{nbat} \mid\}_{4}\right]$<smiles>[R]C([2H])(C(=O)O)N1C(=O)c2ccccc2C1=O</smiles>

$\mathrm{R}=\mathrm{CH}_{2} \mathrm{Ph}:\left[\mathrm{Rh}_{2}\{(\mathrm{~S})-\mathrm{ptpa}\}_{4}\right]$ $\mathrm{R}=t-\mathrm{Bu} \quad:\left[\mathrm{Rh}_{2}\{(\mathrm{~S})-\mathrm{ptt} \mid\}_{4}\right]$<smiles>O=P1(O)Oc2ccc3ccccc3c2-c2c(ccc3ccccc23)O1</smiles>

$\left[\mathrm{Rh}_{2}\{(\mathrm{~S})-\mathrm{bnp}\}_{4}\right]$

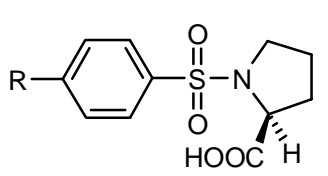

$\mathrm{R}=t-\mathrm{Bu} \quad:\left[\mathrm{Rh}_{2}\{(\mathrm{~S})-\mathrm{tbsp}\}_{4}\right]$ $\mathrm{R}=\mathrm{C}_{12} \mathrm{H}_{25}:\left[\mathrm{Rh}_{2}\{(\mathrm{~S})-\mathrm{dosp}\}_{4}\right]$<smiles>[R]c1ccc(S(=O)(=O)N2C[C@H](O)C[C@H]2CO)cc1</smiles>

$\mathrm{R}=\mathrm{Me} \quad:\left[\mathrm{Rh}_{2}\{(\mathrm{~S}) \text {-tsop }\}_{4}\right]$ $\mathrm{R}=t-\mathrm{Bu}:\left[\mathrm{Rh}_{2}\{(\mathrm{~S}) \text {-tbsop }\}_{4}\right]$

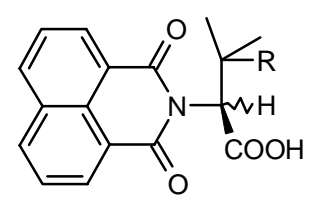

$\mathrm{R}=\mathrm{Me}:\left[\mathrm{Rh}_{2}\{(S)-\mathrm{ntt} \mid\}_{4}\right]$ $\mathrm{R}=\mathrm{H}:\left[\mathrm{Rh}_{2}\{(R)-\mathrm{ntvll}\}_{4}\right]$

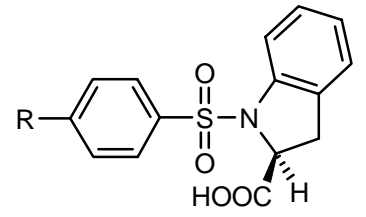

$\mathrm{R}=\mathrm{Me} \quad:\left[\mathrm{Rh}_{2}\{(S)-\operatorname{tsin}\}_{4}\right]$ $\mathrm{R}=t-\mathrm{Bu}:\left[\mathrm{Rh}_{2}\{(\mathrm{~S})-\mathrm{tbsin}\}_{4}\right]$

\section{Scheme 6}

Catalysts. The following chiral catalysts were synthesized according to procedures available in the literature: $\left[\operatorname{Rh}_{2}\{(2 S) \text {-mepy }\}_{4}\right]: \operatorname{Ref}^{24}$; $\left[\operatorname{Rh}_{2}\{(R) \text {-campha }\}_{4}\right]: \operatorname{Ref}^{25}$; $\left[\operatorname{Rh}_{2}\{(S) \text {-bnp }\}_{4}\right]: \operatorname{Ref}^{6}$, $\left.\left[\operatorname{Rh}_{2}\{(S)-p t p a\}_{4}\right]: \operatorname{Ref}^{26}{ }^{2} ; \operatorname{Rh}_{2}\{(S)-p t t l\}_{4}\right]: \operatorname{Ref}^{27} ;\left[\operatorname{Rh}_{2}\{(S) \text {-dosp }\}_{4}\right]: \operatorname{Ref}^{28}{ }^{28}\left[\operatorname{Rh}_{2}\{(S)-n t t l\}_{4}\right]: \operatorname{Ref}^{9}$. The synthesis of $\left[\mathrm{Rh}_{2}\{(S) \text {-tsop }\}_{4}\right],{ }^{29}\left[\mathrm{Rh}_{2}\{(S) \text {-tbsop }\}_{4}\right],{ }^{29}\left[\mathrm{Rh}_{2}\{(S) \text {-tsin }\}_{4}\right],{ }^{29}\left[\mathrm{Rh}_{2}\{(S) \text {-tbsin }\}_{4}\right],{ }^{29}$ $\left[\mathrm{Rh}_{2}\{(S)-n b m a t l\}_{4}\right],{ }^{30}$ and $\left[\mathrm{Rh}_{2}\{(R) \text {-ntvl }\}_{4}\right]^{30}$ will be reported elsewhere.

\section{Synthesis of $\left[\mathrm{Cu}-\{(+) \text {-facam }\}_{2}\right]$}

To $\left[\mathrm{Cu}\left(\mathrm{NO}_{3}\right)_{2} \cdot\left(\mathrm{H}_{2} \mathrm{O}\right)_{3}\right]$ (1.565 g, $\left.6.48 \mathrm{mmol}\right)$ in $\mathrm{H}_{2} \mathrm{O}$ was added aq. $\mathrm{NH}_{3}(2.4 \mathrm{~mL})$ dropwiese, followed by 3-(trifluoroacetyl)-D-camphor (0.805 g, $3.24 \mathrm{mmol})$. The mixture was stirred until formation of a green precipitate. The aqueous layer was extracted with Etz $\mathrm{O}_{2} \mathrm{O}(3 \times 20 \mathrm{~mL})$, which was washed (satd. $\mathrm{NaCl})$ and dried $\left(\mathrm{Na}_{2} \mathrm{SO}_{4}\right)$. The solvent was evaporated, and the residue was recrystallized from hot EtOH to afford [Cu-\{(+)-facam $\left.\}_{2}\right](802 \mathrm{mg}, 88 \%)$ as green crystals, m.p. $151-152{ }^{\circ} \mathrm{C} ;[\alpha]_{\mathrm{D}}{ }^{20}=-10.4\left(\mathrm{c}=0.125, \mathrm{CHCl}_{3}\right)$. IR $\left(\mathrm{CHCl}_{3}\right): 2959 w, 1626 s, 1529 s, 1479 w$, $1455 w, 1440 w, 1420 m, 1392 w, 1371 w, 1329 m, 1299 w, 1285 w, 1268 s, 1224 s, 1200 s, 1178 s$, 1130s. MS: 559 (6), 557 (M+11), 550 (16), 311 (14), 309 (100), 283 (10), 282 (11), 281 (13), 267 (16), 248 (23), 233 (11), 220 (12), 205 (11), 135 (12), 123 (10), 109 (10), 95 (16), 83 (20), 
67 (10), 55 (23). HR MS: $557.1186 \quad\left(\mathrm{C}_{24} \mathrm{H}_{28} \mathrm{O}_{4}{ }^{63} \mathrm{CuF}_{6}{ }^{+}\right.$; calc. 557.1188$) ; \quad 559.1197$ $\left(\mathrm{C}_{24} \mathrm{H}_{28} \mathrm{O}_{4}{ }^{65} \mathrm{CuF}_{6}{ }^{+}\right.$; calc. 557.1170).

\section{Synthesis of diazocyclohexanediones 1a and $4 a$ and phenyliodonium ylides (4b-b)}

The diazocyclohexanediones 1a and 4a were prepared from the respective diketones via diazo transfer with $p$-acetamidobenzenesulfonyl azide ${ }^{31}$ in the presence of base. The procedure failed for $\mathbf{5 a}$, which is, however, available by the procedure of Taber. ${ }^{32}$ The ylides $\mathbf{4 b} \mathbf{b} \mathbf{8 b}$, in turn, were prepared from the hydrocarbons 4c-8c via reaction with $\mathrm{PhI}(\mathrm{OAc})_{2}$, according to Schank and Lick. $^{33}$

Synthesis of 1-oxa-2,2-dimethyl-2,4-dioxo-5-(phenyliodonio)-cyclohexan-5-ide (4b). 1-Oxa2,2-dimethylcyclohexane-4,6-dione (4c). ${ }^{34}$ To $\mathrm{NaH}$ (1.92 g, $\left.80 \mathrm{mmol}\right)$ in anhydrous THF (200 mL) was added, at $0{ }^{\circ} \mathrm{C}$ methyl acetoacetate $(9.28 \mathrm{~g}, 80 \mathrm{mmol})$ dropwise. After $10 \mathrm{~min}$. of stirring BuLi (50 mL, 1.6M, $80 \mathrm{mmol}$ ) was added dropwise, and the orange solution was stirred at $0{ }^{\circ} \mathrm{C}$ for 10 more min. Dry acetone $(7.5 \mathrm{~mL}, 82 \mathrm{mmol})$ was added at once, and the mixture was stirred for $10 \mathrm{~min}$. at $0{ }^{\circ} \mathrm{C}$. $\mathrm{NaOH}(80 \mathrm{~mL}, 2.5 \mathrm{M})$ was then added, and the mixture was stirred at r.t. during $12 \mathrm{~h}$, whereupon it was acidified $(2.5 \mathrm{M} \mathrm{HCl})$ and extracted with ether $(3 \times 200 \mathrm{~mL})$. The organic layer was washed (satd. $\mathrm{NaCl})$ and dried $\left(\mathrm{Na}_{2} \mathrm{SO}_{4}\right)$. After filtration, the solvant was evaporated. The residue was dissolved in a minimum of $\mathrm{CH}_{2} \mathrm{Cl}_{2}$, and $4 \mathrm{c}(4.82 \mathrm{~g}, 42 \%)$ was precipitated with pentane as brownish solid, m.p. 126-127 ${ }^{\circ} \mathrm{C}$. IR $\left(\mathrm{CHCl}_{3}\right)$ : 2974w, 2361s, 2339s, $1647 m, 1576 m, 1342 m, 1321 m, 1236 m, 1176 m, 1110 m, 999 m .{ }^{1} \mathrm{H}$ NMR (500 $\left.\mathrm{MHz}, \mathrm{CDCl}_{3}\right)$ : $1.48(\mathrm{~s}, 6 \mathrm{H}) ; 2.66(\mathrm{~s}, 2 \mathrm{H}) ; 3.40(\mathrm{~s}, 2 \mathrm{H}) .{ }^{13} \mathrm{C} \mathrm{NMR}\left(125 \mathrm{MHz}, \mathrm{CDCl}_{3}\right): 28.3(q) ; 44.9(t) ; 50.4(t)$; 79.1 (d); 167.3 (s); 200.6 (s). MS: $142\left(\mathrm{M}^{+}, 10\right), 127$ (25), 85 (45), 84 (46), 83 (27), 70 (12), 59 (10), 56 (100), 55 (13). HR MS: $142.0618\left(\mathrm{C}_{7} \mathrm{H}_{15} \mathrm{O}_{3}{ }^{+}\right.$; calc. 142.0630).

1-Oxa-2,2-dimethyl-2,4-dioxo-5-(phenyliodonio)-cyclohexan-5-ide (4b). ${ }^{33}$ Prepared in 93\% yield from 4c. M.p. $133{ }^{\circ}$ C. IR (film): 2990w, 1640w, 1558s, 1470w, 1428w, 1289m, 1168w, 1030w, 989w, 899w, 747m. ${ }^{1} \mathrm{H}$ NMR $\left.500 \mathrm{MHz}, \mathrm{CDCl}_{3}\right): 1.46$ (s, 6H); 2.69 (s, 2H); 7.38-7.57 (m, 3H); 7.85-7.87 (m, 2H). ${ }^{13} \mathrm{C}$ NMR (125 MHz, $\left.\mathrm{CDcl}_{3}\right)$ : $27.3(q) ; 47.2(t) ; 74.7(s) ; 113.3(s) ; 127.4$ (s); 130.2 (d); $131.8(d) ; 133.5(d) ; 165.7$ (s); 184.1 (s). MS: $344\left(\mathrm{M}^{+}, 9\right), 293$ (19), 204 (75), 167 (12), 149 (87), 127 (18), 85 (17), 83 (11), 77 (100), 71 (28), 70 (13), 69 (11), 57 (25), 56 (10), 55 (12), 51 (46), 50 (24). HR MS: $343.9904\left(\mathrm{C}_{13} \mathrm{H}_{13} \mathrm{O}_{3} \mathrm{I}^{+}\right.$; calc. 343.9910).

2,3-Benzo-4,6-dioxo-5-(phenyliodonio)-1-oxacyclohexan-5-ide (5b). ${ }^{33}$ Prepared in 89 \% yield from 4-hydroxycoumarin (5c). M.p. $142{ }^{\circ} \mathrm{C}$ (Lit. $135{ }^{\circ} \mathrm{C}$ ). IR (film): 3050w, 1652m, 1591m, 1538s, 1460w, 1344w, 1283m, 1192m, 961m, 889w, 730s. ${ }^{1} \mathrm{H}$ NMR (300 $\mathrm{MHz}^{\left.-\mathrm{CDCl}_{3}\right): 7.22-}$ 7.25 (m, 2H); 7.39-7.60 (m, 4H); 7.95-8.07 (m, 3H). ${ }^{13} \mathrm{C}$ NMR (75 MHz, $\left.\mathrm{CDCl}_{3}\right): 80.5$ (s); 112.2 $(d) ; 116.7(d) ; 119.8(s) ; 123.8(d) ; 126.3(d) ; 132.0(d) ; 132.2(d) ; 133.3(d) ; 134.3(d) ; 154.3(s)$; 161.8 (s); 174.1 (s). MS: 364 (M+23), 237 (20), 204 (100), 197 (12), 77 (94), 76 (10), 51 (37), 50 (22). HR MS: $363.9585\left(\mathrm{C}_{15} \mathrm{H}_{9} \mathrm{O}_{3} \mathrm{I}^{+}\right.$; calc. 363.9597).

1-Methyl-2,3-benzo-4,6-dioxo-5-(phenyliodonio)-1-azacyclohexan-5-ide (6b). Pre-pared from (6c) in 99 \%, yield; m.p. $130{ }^{\circ} \mathrm{C}$. IR (film): 3000w, 1586m, 1513s, 1469m, 1411w, 1356w, $1314 m, 1210 m, 1156 w, 1110 w, 1070 w, 1040 w, 991 m, 747 s, 726 s, 678 s .{ }^{1} \mathrm{H}$ NMR (400 MHz, 
$\left.\mathrm{CDCl}_{3}\right): 2.10(\mathrm{~s}, 3 \mathrm{H}) ; 7.01-7.09(\mathrm{~m}, 3 \mathrm{H}) ; 7.39-7.44(\mathrm{~m}, 2 \mathrm{H})$; 7.62-7.65 (m, 1H); 7.84-7.87 (m, 2H); 8.12-8.14 (m, 1H). ${ }^{13} \mathrm{C}$ NMR (100 MHz, $\left.\mathrm{CDCl}_{3}\right)$ : 302. (q); 112.5 (s); $113.8(d) ; 114.2(s)$; $121.3(s) ; 121.5(d) ; 127.3(d) ; 130.2(d) ; 131.5(d) ; 133.9(d) ; 137.5(d) ; 141.3(s) ; 161.6(s) ;$ 173.3 (s). MS: 377 (M+100), 378 (16), 251 (15), 250 (93), 249 (10), 235 (22), 222 (13), 125 (22), 77 (17), 51 (11). HR MS: $376.9909\left(\mathrm{C}_{16} \mathrm{H}_{12} \mathrm{O}_{2} \mathrm{NI}^{+}\right.$; calc. 376.9913).

6-Methyl-2,4-dioxo-3-(phenyliodonio)-1-oxacyclohexan-3-ide (7b). ${ }^{33}$ Prepared in $82 \%$ yield from 4-hydroxy-6-methyl-4-pyrone (7c). M. p. $145{ }^{\circ} \mathrm{C}$. IR (film): 3073w, 1651s, 1567w, 1532s, $1477 m, 1441 \mathrm{~m}, 1390 \mathrm{~m}, 1365 \mathrm{~m}, 129 \mathrm{~m}, 1250 \mathrm{~m}, 991 \mathrm{~m}, 909 \mathrm{~m} .{ }^{1} \mathrm{H}$ NMR (500 MHz, $\left.\mathrm{CDCl}_{3}\right): 2.15$ $(d, J=0.6,3 \mathrm{H}) ; 5.76(d, J=0.6,1 \mathrm{H}) ; 7.39-7.49(m, 2 \mathrm{H}) ; 7.56-7.59(\mathrm{~m}, 1 \mathrm{H}) ; 7.91-7.93(m, 2 \mathrm{H})$. ${ }^{13} \mathrm{C}$ NMR (125 MHz, $\left.\mathrm{CDCl}_{3}\right): 19.4(q) ; 79.9(s) ; 106.0(d) ; 112.3(d) ; 132.0(d) ; 132.1(d) ; 134.1$ (d); 162.8 (s); 163.0 (s); 176.9 (s). MS: 328 (M+, 89), 204 (66), 201 (38), 161 (45), 105 (22), 102 (10), 94 (37), 77 (100), 74 (10), 65 (13), 51 (48), 50 (27). HR MS: $327.9594\left(\mathrm{C}_{12} \mathrm{H}_{9} \mathrm{O}_{3} \mathrm{I}^{+}\right.$; calc. 327.9597).

1,3-Dimethyl-2,4,6-trioxo-5-(phenyliodonio)-1,3-diazacyclohexan-5-ide (8b). ${ }^{35}$ Prepared from 1,3-dimethylbarbituric acid (8c) according to Schank and Lick. ${ }^{33}$ IR $\left(\mathrm{CHCl}_{3}\right): 1689$, 1623. ${ }^{1} \mathrm{H}$ NMR (500 MHz, $\left.\mathrm{CD}_{2} \mathrm{Cl}_{2}\right): 3.15$ (s, 6H); $7.44(\mathrm{~m}, 2 \mathrm{H}) ; 7.59(t t, J=7.4,1.0,1 \mathrm{H}) ; 7.85$ (dd, $J=$ 8.5, 1.0, 2H). ${ }^{13} \mathrm{C}$ NMR (125 MHz, DMSO): $29.0(q) ; 70.4(s) ; 116.5(s) ; 131.0(d) ; 131.5(d)$; $132.8(d) ; 153.1(s) ; 161.3$ (s). MS: $358\left(\mathrm{M}^{+},<1\right), 231$ (2), 205 (7), 204 (100), 127 (6), 78 (7), 77 (96). HR MS: $357.9850\left(\mathrm{C}_{12} \mathrm{H}_{11} \mathrm{IN}_{2} \mathrm{O}_{3}{ }^{+}\right.$; calc. 357.9814).

Cyclopropanation and cycloaddition with diazo compounds and phenyliodonium ylides. General procedure

The carbene precursor (diazo compound or phenyliodonium ylide, respectively,1.00 mmol) and the appropriate olefin $(10.0 \mathrm{mmol})$ were dissolved in were dissolved in the appropriate solvent $(10 \mathrm{ml})$ indicated in the Tables. After addition of the catalyst $(0.02 \mathrm{mmol})$ the mixture was stirred at the temperature indicated under $\mathrm{N}_{2}$ overnight. The solvent was evaporated and the residue was purified by flash chromatography $\left(\mathrm{SiO}_{2}\right.$, EtOAc/pentane 1:4).

\section{Cyclopropanation of terminal olefins}

6,6-Dimethyl-1-phenylspiro[2.5]octane-4,8-dione (9a). Yield $33 \%$ for $\left.\left[\mathrm{Rh}_{2} \mathrm{OAc}\right)_{4}\right]$. M.p. 127 $120^{\circ}$. IR (KBr): 3361w, 3063w, 2951m, 2871m, 1700s, 1679s. ${ }^{1} \mathrm{H}$ NMR (500 MHz, CDCl $): 0.97$ (s, $3 \mathrm{H}) ; 1.06$ (s, $3 \mathrm{H}) ; 2.10$ - 2.30 (m, $2 \mathrm{H}) ; 2.25$ (dd, J = 9.2, 3.8, $1 \mathrm{H}) ; 2.46$ (dd; J = 8.8, 3.9, 1 $\mathrm{H}) ; 2.48-2.58$ (m, $2 \mathrm{H}) ; 7.14$ - 7.22 (m, $5 \mathrm{H}) .{ }^{13} \mathrm{C}$ NMR (125 MHz, $\left.\mathrm{CDCl}_{3}\right): 22.1$ (z); $27.9(q)$; $29.3(q) ; 30.5(s) ; 48.5(d) ; 48.7(s) ; 53.2(t) ; 54.0(t) ; 128.0(d) ; 128.1(d) ; 129.5(d) ; 133.2(s)$; 201.7 (s); 205.6 (s). MS: 242 (100), 241 (11), 186 (18), 184 (64), 171 (47), 158 (15), 157 (12), 144 (41), 129 (13), 116 (22), 115 (41), 105 (16), 104 812), 91 (12), 83 (40), 55 (20). HR MS: $242.1313\left(\mathrm{C}_{16} \mathrm{H}_{18} \mathrm{O}_{2}{ }^{+}\right.$; calc. 242.1307). Enantiomer separation: HPLC, OD-H, isopropanol /hexane 1:9, $0.3 \mathrm{~mL} / \mathrm{min} . \tau_{1}=28.4, \tau_{2}=30.8 \mathrm{~min}$.

6,6-Dimethyl-2-phenyl-3,4,6,7-tetrahydro-2H-benzofuran-4-one (10a). Yield $19 \%$, oil. IR $\left(\mathrm{CHCl}_{3}\right): 1630 s .{ }^{1} \mathrm{H}$ NMR (500 MHz, $\left.\mathrm{CDCl}_{3}\right): 1.15$ (s, $\left.3 \mathrm{H}\right) ; 1.16$ (s, $\left.3 \mathrm{H}\right) ; 2.27$ (d, J = 16.0, 1 $\mathrm{H})$; 2.18 - 2.39 (m, $2 \mathrm{H})$; $2.31(d, J=16.0,1 \mathrm{H}) ; 2.89$ (ddt, $J=16.4,7.9,1.9,1 \mathrm{H})$; 3.30 (ddt; $J=$ 16.4, 10.7, 1.9, $1 \mathrm{H})$; 5.78 (dd, $J=10.4,7.9,1 \mathrm{H})$; $7.29-7.41(m, 5 \mathrm{H}) .{ }^{1} \mathrm{C}$ NMR $(125 \mathrm{MHz}$, 
CDCl3): $28.6(q) ; 28.8(q) ; 33.9(t) ; 34.2(s) ; 37.8(t) ; 51.0(t) ; 86.5(d) ; 111.4(s) ; 125.8(d)$; $128.5(d) ; 128.8(d) ; 140.7(s) ; 176.0(s) ; 194.7(s) . M S: 242\left(\mathrm{M}^{+}, 100\right), 241(12), 186(19), 185$ (56), 171 (40), 158 (14), 157 (11), 144 (33), 129 (10), 116 (16), 115 (30),105 (13), 83 (32), 55 (15). HR MS: $242.1328\left(\mathrm{C}_{16} \mathrm{H}_{18} \mathrm{O}_{2}{ }^{+}\right.$; calc. 242.1307). Enantiomer separation: HPLC, OD-H, isopropanol /hexane $1: 9,0.3 \mathrm{~mL} / \mathrm{min} . \tau_{1}=24.5, \tau_{2}=39.5 \mathrm{~min}$.

6,6-Dimethyl-1-propylspiro[2.5]octane-4,8-dione (9b). Yield 34 \%. IR $\left(\mathrm{CHCl}_{3}\right):{ }^{1} \mathrm{H}$ NMR (500 $\left.\mathrm{MHz}, \mathrm{CDCl}_{3}\right)$ : $0.88(t, J=7.3,3 \mathrm{H}) ; 1.06(\mathrm{~s}, 3 \mathrm{H}) ; 1.18$ - $1.37(m, 2 \mathrm{H}) ; 1.44$ - $1.58(\mathrm{~m}, 3 \mathrm{H})$; 1.85 (dd, $J=8.5,2.5,1 \mathrm{H}) ; 2.01(d d, J=8.5,2.5,1 \mathrm{H}) ; 2.04-2.09(m, m, 1 \mathrm{H}) ; 2.48$ - 2.58 (m, 1 H). ${ }^{13} \mathrm{C}$ NMR (125 MHz, $\left.\mathrm{CDCl}_{3}\right): 13.7(q) ; 22.5(t) ; 27.2(t) ; 27.6(q) ; 28.5(t) ; 29.4(q) ; 30.5(s)$; $45.5(s) ; 46.5(d) ; 53.1(t) ; 54.3(t) ; 204.9$ (s); 206.9 (s). MS: 208 (M+, 40), 193 (19), 179 (32), 166 (20), 165 (54), 153 (60), 152 (26), 141 (11), 137 (37), 124 (29), 123 (32), 110 (18), 109 (29), 98 (11), 97 (100), 96 (10), 95 (35), 83 (29), 82 (22), 81 (27), 79 (11), 77 (11), 69 (45), 68 (23), 67 (27), 57 (10), 56 (19), 55 (68), 54 (18), 53 (40). HR MS: $208.1461\left(\mathrm{C}_{13} \mathrm{H}_{20} \mathrm{O}_{2}{ }^{+}\right.$; calc. 208.1463).

1-n-Butyl-6,6-dimethylspiro[2.5]octane-4,8-dione (9c). Yield 31 \%. IR ( $\left.\mathrm{CHCl}_{3}\right)$ : 2961w, 1675s, 1371w, 1339w, 1256w. ${ }^{+} \mathrm{H}$ NMR (400 MHz, $\left.\mathrm{CDCl}_{3}\right): 0.87$ (t, $\left.J=6.8,3 \mathrm{H}\right) ; 1.06$ (s, $\left.3 \mathrm{H}\right)$; 1.16 (s, $3 \mathrm{H}) ; 1.17$ - 1.35 (m, $4 \mathrm{H}) ; 1.44$ - 1.61 (m, $2 \mathrm{H}) ; 1.85$ (dd, $J=8.1,2.0,1 \mathrm{H}) ; 2.48$ - 2.58 (m, $4 \mathrm{H}) .{ }^{13} \mathrm{C}$ NMR (100 MHz, $\left.\mathrm{CDCl}_{3}\right): 13.9(q) ; 22.2(t) ; 26.1(t) ; 27.2(t) ; 27.5(q) ; 29.3(q)$; $30.4(s) ; 31.4(t) ; 45.5(s) ; 46.6(d) ; 53.1(t) ; 54.2(t) ; 204.8(s) ; 206.8(s)$. MS: $223(13) ; 222\left(\mathrm{M}^{+}\right.$, 66), 207 (17), 193 (54), 180 (27), 179 (34), 167 (12), 166 (38), 165 (60), 154 (27), 153 (77), 151 (18), 141 (16), 138 (13), 137 (45), 124 (20), 123 (29), 110 (10), 109 (16), 98 (26), 97 (100), 96 (16), 95 (28), 83 (51), 82 (28), 81 (25), 79 (10), 77 (10), 70 (11), 69 (32), 68 (14), 67 (21), 56 (11), 55 (55), 54 (13), 53 (23). HR MS: $222.1625\left(\mathrm{C}_{14} \mathrm{H}_{22} \mathrm{O}_{2}{ }^{+}\right.$; calc. 222.1620). Enantiomer separation: GC, $\beta$-Dex, isothermal at $150{ }^{\circ} \mathrm{C} ; \tau_{1}=27.6, \tau_{2}=28.2 \mathrm{~min}$.

1-t-Butyl-6,6-dimethylspiro[2,5]octane-4,8-dione (9d). Yield $25 \%$. IR ( $\left.\mathrm{CHCl}_{3}\right)$ : 2960w, 1672s, 1334w. ${ }^{1} \mathrm{H}$ NMR (500 MHz, $\mathrm{CDCl}_{3}$ ): 0.96 (s, $\left.9 \mathrm{H}\right) ; 0.97$ (s, $\left.3 \mathrm{H}\right) ; 1.18$ (t, J = 9.6, $1 \mathrm{H}$ ); $1.97(d d, J=9.6,3.3,1 \mathrm{H}) ; 2.20(d d, J=9.6,3.3,1 \mathrm{H}) ; 2.46-2.67(m, 4 \mathrm{H}) .{ }^{13} \mathrm{C}$ NMR $(125$ $\left.\mathrm{MHz}, \mathrm{CDCl}_{3}\right)$ : $21.7(t) ; 26.6(q) ; 29.8(q) ; 30.2(q) ; 30.7(s) ; 32.3(s) ; 47.0(s) ; 53.2(t) ; 55.5(t)$; 58.5 (d); 204.9 (s); 206.(s). MS: $222\left(\mathrm{M}^{+}, 5\right), 207$ (19), 179 (56), 165 (13), 97 (41), 83 (11), 70 (100), 69 (14), 55 (37). HR MS: $222.1611\left(\mathrm{C}_{14} \mathrm{H}_{22} \mathrm{O}_{2}{ }^{+}\right.$; calc. 222.1620). Enantiomer separation: GC, $\beta$-Dex, isothermal at $120{ }^{\circ} \mathrm{C} ; \tau_{1}=29.5, \tau_{2}=30.4 \mathrm{~min}$.

\section{Cycloaddition to furan and dihydrofuran with 4a,b}

6,6-Dimethyl-3a,6,7,8a-tetrahydro-1,5,8-trioxacyclopenta[a]inden-4-one (11). ${ }^{1} \mathrm{H}$ NMR (200 $\mathrm{MHz}_{\mathrm{CDCl}}$ ): $1.47(\mathrm{~s}, 3 \mathrm{H}) ; 1.49(\mathrm{~s}, 3 \mathrm{H}) ; 2.59(\mathrm{~d}, \mathrm{~J}=1.8,2 \mathrm{H}) ; 4.35-4.38(\mathrm{~m}, 1 \mathrm{H})$; 5.42-5.44 (m, $1 \mathrm{H})$; 6.42-6.44 $(m, 1 \mathrm{H})$; $6.67(d, J=7.5,1 \mathrm{H})$. Enantiomer separation by GC, $\beta$-dex, isothermal, $150{ }^{\circ} \mathrm{C}, \tau_{1}=34.1, \tau_{2}=34.8 \mathrm{~min}$.

6,6-Dimethyl-2,3,3a,6,7,8a-hexahydro-1,5,8-trioxacyclopenta[a]inden-4-one (12). Yield 48 \%, m.p. 125 - $126{ }^{\circ} \mathrm{C}$. IR (film): 2972w, 2867w, 1727w, 1687s, 1664s; 1438w, 1406m, $1363 m, 1239 s, 1202 w, 1181 m, 1114 s, 1083 s, 1045 s, 934 s, 905 m, 880 s .{ }^{1} \mathrm{H}$ NMR (300 MHz, 
$\left.\mathrm{CDCl}_{3}\right): 1.47(\mathrm{~s}, 6 \mathrm{H}) ; 2.00-2.23(\mathrm{~m}, 2 \mathrm{H}) ; 2.49-2.63(\mathrm{~m}, 2 \mathrm{H}) ; 3.64-3.73(\mathrm{~m}, 1 \mathrm{H}) ; 3.78(t b r, J=7$, $1 \mathrm{H}) ; 4.14(t, 1 \mathrm{H}) ; 6.32(d, J=5.8,1 \mathrm{H}) .{ }^{13} \mathrm{C} \mathrm{NMR}\left(75 \mathrm{MHz}, \mathrm{CDCl}_{3}\right): 28.0(q) ; 28.1(q) ; 30.3(t)$;

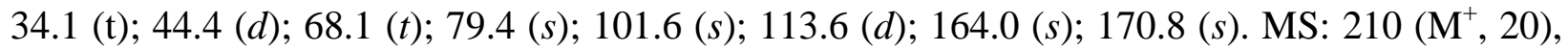
192 (29), 177 (15), 155 (18), 154 (63), 149 (24), 137 (12), 136 (24), 126 (20), 110 14), 109 (20), 108 (19), 105 (14), 98 (18), 97 (15), 95 (12), 91 (15), 85 (17), 83 (1009, 82 (17), 81 (21), 80 (12), 79 (10), 77 (10), 71 (26), 70 (21), 69 (42), 68 (10), 67 (11), 58 (11), 57 (37), 56 (26), 55 (51), 54 (13), 52 (10), 51 (10). HR MS: $210.0911\left(\mathrm{C}_{11} \mathrm{H}_{14} \mathrm{O}_{4}{ }^{+}\right.$; calc. 210.0892). Enantiomer separation by GC, $\beta$-dex, isothermal, $150{ }^{\circ} \mathrm{C}, \tau_{1}=44.1, \tau_{2}=45.9 \mathrm{~min}$.

Crystallographic data for 12. $\mathrm{C}_{11} \mathrm{H}_{14} \mathrm{O}_{4} ; \mathrm{M}_{\mathrm{r}}=210.3 ; \mu=0.10 \mathrm{~mm}^{-1}, \mathrm{~d}_{\mathrm{X}}=1.370 \mathrm{~g} \cdot \mathrm{cm}^{-3}$, monoclinic, $P \quad \overline{1}, \mathrm{Z}=2$, a = 6.9812(15), $\mathrm{b}=8.855(2)$, $\mathrm{c}=8.854(2) \AA, \alpha=107.93(3), \beta=$ 99.44(3), $\gamma=93.80(3)^{\circ}, V=509.7(3) \AA^{3}$; Data were collected at $200 \mathrm{~K}$ on a Stoe IPDS diffractometer. Hydrogen atoms were observed and refined. $R=0.036, \omega R=0.033, S=1.24(3)$. Crystallographic data for $\mathbf{1 2}$ (excluding structure factors) have been deposited to the Cambridge Crystallographic Data Base as supplementary publication number CCDC 204495. Copies of the data can be obtained free of charge on application to the CCDC, 12 Union Road, Cambridge CB2 1EZ, UK (fax: Int. + 44 (1223) 336-033; e-mail: deposit@ccdc.cam.ac.uk).

\section{Cycloaddition of furan and dihydrofuran with $6 b$}

6,7-Benzo-3a,8a-dihydro-1,5,8-trioxacyclopenta[a]inden-4-one (16). M.p. $135{ }^{\circ} \mathrm{C}$. IR (film): $2919 b r, 1710 s, 1646 m, 1614 w, 1569 w, 1496 w, 1410 m, 1326 w, 1229 w, 1126 w, 1006 w, 977 w$, 914m, 898m, 759s. ${ }^{1} \mathrm{H}$ NMR (500 MHz, $\left.\mathrm{CDCl}_{3}\right): 4.66(d, J=5.0,1 \mathrm{H})$; 5.53-5.54 (m, 1H); 6.516.52 (m, 1H); 6.91-6.92 (m, 1H); 7.32-7.34 (m, 1H); 7.39-7.40 (m, 1H); 7.58-7.59 (m, 1H); 7.72$7.74(m, 1 \mathrm{H}) .{ }^{13} \mathrm{C}$ NMR (125 MHz, $\left.\mathrm{CDCl}_{3}\right): 29.7(s) ; 30.9(s) ; 48.8(d) ; 102.6(d) ; 104.9(s)$; $112.0(s) ; 113.8(d) ; 117.0(d) ; 123.2(d) ; 124.2(d) ; 132.8(d) ; 145.3(d) ; 160.0(s) . M S: 228\left(\mathrm{M}^{+}\right.$, 40), 201(12), 200 (93), 199 (38), 171 (16), 144 (14), 121 (100), 120 (11), 118 (10), 115 (24), 108 (37), 93 (19), 92 (23), 89 (10), 80 (13), 79 (10), 77 (13), 73 (16), 71 (14), 69 (15), 65 (23), 64 (17), 63 (25), 62 (10), 60 (14), 57 (32), 56 (10), 55 (26), 53 (12), 52 (12), 51 (19), 50 (14). HR MS: $228.0434\left(\mathrm{C}_{13} \mathrm{H}_{8} \mathrm{O}_{4}{ }^{+}\right.$; calc. 228.0423). Enantiomer separation: HPLC, OD-H column, isopropanol/hexane 1:9, $0.5 \mathrm{~mL} / \mathrm{min}$; $\tau_{1}=23.3$, $\tau_{2}=25.9 \mathrm{~min}$.

6,7-Benzo-2,3,3a,8a-tetrahydro-1,5,8-trioxacyclopenta[a]inden-4-one (17). M.p. $137{ }^{\circ} \mathrm{C}$. IR (film): 3056w, 2956br, 1715m, 1643w, 1499w, 1416w, 1264m, 1156w, 1075m, 1003w, 942w, 862w, 732s, 702m. ${ }^{1} \mathrm{H}$ NMR (500 MHz, $\left.\mathrm{CDCl}_{3}\right): 2.13-2.15$ (m, 1H); 2.25-2.27 (m, 1H); 3.653.68 (m, 1H); 3.98-3.99 (m, 1H); 4.11-4.15 (m, 1H); 6.50 (d, J = 5.8, 1H); 7.20-7.24 (m, 1H); 7.29-7.30 (m, 1H); 7.48-7.52 (m, 1H); 7.61-7.63 (m, 1H). ${ }^{13} \mathrm{C}$ NMR (125 MHz, $\left.\mathrm{CDCl}_{3}\right): 30.1(t)$; $44.8(d) ; 68.3(t) ; 102.4(s) ; 111.8(s) ; 114.5(d) ; 116.9(d) ; 123.2(d) ; 124.1(d) ; 132.7(d) ; 154.9$ (s); 159.9 (s); 166.5 (s). MS: 230 (M+ , 46), 215 (15), 202 (18), 201 (11), 187 (45), 121 (100), 120 (11), 108 (10), 93 (12), 92 (17), 82 (26), 65 (13), 64 (12), 63 (13), 57 (10), 53 (15). HR MS: $230.0586\left(\mathrm{C}_{13} \mathrm{H}_{10} \mathrm{O}_{4}{ }^{+}\right.$; calc. 230.0579). Enantiomer separation: HPLC, OD-H column, isopropanol/hexane 1:9, $0.5 \mathrm{~mL} / \mathrm{min}$; $\tau_{1}=27.6, \tau_{2}=31.0 \mathrm{~min}$. 
Crystallographic data for 17. $\mathrm{C}_{13} \mathrm{H}_{10} \mathrm{O}_{4} ; \mathrm{M}_{\mathrm{r}}=230.2 ; \mu=0.11 \mathrm{~mm}^{-1}, \mathrm{~d}_{\mathrm{X}}=1.458 \mathrm{~g} \cdot \mathrm{cm}^{-3}$, monoclinic, $P 2{ }_{1} / \mathrm{c}, \mathrm{Z}=4$, a = 10.4043(10), $\mathrm{b}=8.7026(9), \mathrm{c}=12.5505(13) \AA, \beta=112.635(11)^{\circ}$, $\mathrm{V}=1048.8(2) \AA^{3}$; Data were collected at $200 \mathrm{~K}$ on a Stoe IPDS diffractometer. Hydrogen atoms were observed and refined. $R=0.031, \omega R=0.030, S=1.21(3)$. Crystallographic data for 17 (excluding structure factors) have been deposited to the Cambridge Crystallographic Data Base as supplementary material, publication number CCDC 204496.

5,6-Benzo-3-iodo-5-phenoxy-1-oxacyclohex-3-en-2-one (18). M.p. $131{ }^{\circ} \mathrm{C}$. IR (film): $3011 \mathrm{br}$, $1739 m, 1719 s, 1606 m, 1555 m, 1483 m, 1339 s, 1083 w, 1033 w, 978 w, 775 w .{ }^{1} \mathrm{H}$ NMR $300 \mathrm{MHz}$, $\left.\mathrm{CDC}_{3}\right)$ : 6.95-6.99 (m, 2H); 7.15-7.22 (m, 2H); 7.34-7.46 (m, 3H); 7.53-7.61 (m, 2H). ${ }^{13} \mathrm{C}$ NMR (75 MHz, $\left.\mathrm{CDCl}_{3}\right): 80.5(s) ; 115.9(d) ; 116.3(s) ; 116.9(d) ; 123.7(d) ; 123.9(d) ; 124.6(d) ; 130.1$ (d); $133.0(d) ; 153.4(s) ; 155.4(s) ; 155.7$ (s); 165.0 (s). MS: 364 (M+1 100), 365 (17), 238 (16), 237 (94), 236 (10), 209 (14), 197 (42), 193 (16), 181 (17), 165 (41), 152 (13), 116 (15), 88 (27), 77 (25), 76 (17), 62 (16), 51 (19), 50 (10). HR MS: $363.9602\left(\mathrm{C}_{15} \mathrm{H}_{9} \mathrm{O}_{3} \mathrm{I}^{+}\right.$; calc. 363.9597).

Supporting Information Available. Crystal data, intensity measurement and structure refinement, atomic coordinates, displacement parameters, bond distances and bond angles for 12 and $\mathbf{1 7}$ and CIF files.

\section{Acknowledgments}

This work was supported by the Swiss National Science Foundation (Projects No. 20-52581.97 and 2027-048156) and by the European Commission for Science, Research and Development (COST Action D12). The authors are indebted to A. Pinto and J.-P. Saulnier for the NMR spectra, D. Klink for the mass spectra, and E. Robert for the preparation of $\mathbf{8 b}$.

\section{References}

1. (a) Müller, P.; Boléa, C. Helv. Chim. Acta 2001, 84, 1093. (b) Müller, P.; Boléa, C. Synlett 2001, 826. (c) Müller, P.; Fernandez, D. Helv. Chim. Acta 1995, 78, 947. (d) Müller, P.; Fernandez, D.; Nury, P.; Rossier, J.-C. J. Phys. Org. Chem. 1998, 11, 321.

2. (a) Lydon, K. M.; McKervey, M. A. In Comprehensive Asymmetric Catalysis, Jacobsen, E. N.; Pfaltz, A.; Yamamoto, Eds; H. Springer: Berlin, 1999; Vol. II, p 539. (b) Doyle, M. P.; McKervey, M. A. Modern Catalytic Methods for Organic Synthesis with Diazo Compounds, Wiley: New York, 1997. (c) Doyle, M. P.; Forbes, D. C. Chem. Revs. 1998, 98, 911.

3. (a) Wenkert, E.; Alonso, M. E.; Buckwalter, B. L.; Chou, J. K. J. Am. Chem. Soc. 1977, 99, 4778. (b) Alonso, M. E.; Morales, A.; Chitty, A. W. J. Org. Chem. 1982, 47, 3747.

4. (a) Alonso, M. E.; Jano, P.; Hernandez, M. L.; Greemberg, R. S.; Wenkert, E. J. Org. Chem. 1983, 48, 3047. (b) Wenkert, E.; Alonso, M. E.; Buckwalter, B. L.; Sanchez, J. Am. Chem. 
Soc. 1983, 105, 2021. (c) E. Wenkert, T. P. Anantanarayan, V. F. Ferreira, M. G. Hoffmann, H.-S. Kim, E. L. J. Org. Chem. 1990, 55, 4975.

5. Pirrung, M. C.; Zhang, J.; McPhail, A. T. J. Org. Chem. 1991, 56, 6269.

6. $\quad$ Pirrung, M. C.; Zhang, J. Tetrahedron Lett. 1992, 33, 5987.

7. Ishitani, H. Achiwa, K. Heterocycles 1997, 46, 153.

8. Müller, P.; Allenbach, Y.; Ferri, M. Helv. Chim. Acta 2003, in preparation.

9. Müller, P.; Allenbach, Y.; Robert, E. Tetrahedron: Asymmetry 2003 in the press.

10. Matlin, S. A. ; Lough, W. J.; Chan, L.; Abram, D. M. H.; Zhou, Z. J. Chem. Soc. Chem. Commun. 1994, 1038.

11. Pfaltz, A. In Comprehensive Asymmetric Catalysis, Jacobsen, E. N.; Pfaltz, A.; Yamamoto, H. Eds; Springer, Berlin, 1999; Vol. II, p 513.

12. Kurganov, A. A.; Zhuchova, L. YA.; Davankov, V. A. Tetrahedron 1983, 2, 37.

13. Yoshida, J.; Yano, S.; Ozawa, T.; Kawabata, N. J. Org. Chem. 1985, 50, 3467.

14. SpecTool 2.1 A Hypermedia Book for Structure Elucidation of Organic Compounds with Spectroscopic Methods. Gloor, A.; Cadisch, M.; Bürgin-Schaller, R.; Farkas, M.; Kocsis, T.; Clerc, J. T.; Pretsch, E.; Aeschimann, R.; Badertscher, M.; Brodmeier, T.; Fürst, A.; Hediger, H.-J.; Junghans, M.; Kubinyi, H.; Munk, M. E.; Schriber, H.; Wegmann, D.; Kiedorf, U.; Moll, R. Chemical Concepts GmbH, P.O. Box 1002 02, D-69442 Weinheim.

15. Takaku, M.; Hayasi, Y.; Nozaki, H. Tetrahedron 1970, 26, 1243.

16. Neilands, O. Latvian J. Chem. 2002, 27.

17. Moriarty, R. M.; Bailey, B. R.; Prakash, O.; Prakash, I. J. Am. Chem. Soc. 1985, 107, 1375.

18. Pirrung, M. C.; Blume, F. J.Org. Chem. 1999, 64, 3642.

19. Davies, H. M. L.; Panaro, S. A. Tetrahedron 2000, 56, 4871.

20. Müller, P.; Maîtrejean, E. Coll. Czech. Chem. Commun. 1999, 64, 1807.

21. (a) Tokunoh, R.; Fähndrich, B.; Pfaltz, A. Synlett. 1995, 491. (b) Piqué, C.; Tomiyana, H.; Sodeoka, M.; Shibasaki, M. Tetrahedron Lett. 1996, 37, 2449. (c) Doyle, M. P.; Eismont, M. Y.; Zhou, Q.-L. Russ. Chem. Bull. 1977, 46, 955.

22. (a) Estevan, F.; Herbst, K.; Lahuerta, P.; Barberis, M.; Pérez-Prieto, J. Organometallics 2001, 20, 950. (b) Barberis, M.; Lahuerta, P.; Pérez-Prieto, J.; Sanaú, M. J. Chem. Soc. Chem. Commun. 2001, 439. (c) Barberis, M.; Pérez-Prieto, J.; Stribia, S.-E.; Lahuerta, P. Org. Lett. 2001, 3, 3317.

23. Müller, P.; Nury, P. Helv. Chim. Acta 2001, 84, 662.

24. Doyle, M. P.; Winchester, W. R.; Protopopova, M. N.; Kazala, A.; Westrum, L. Org. Synth. 1996, 73, 13.

25. Roos, G. H. P.; McKervey, M. A. Synth. Comm. 1992, 22, 1751.

26. (a) Hashimoto, S.-I.; Watanabe, N.; Ikegami, S. Tetrahedron Lett. 1990, 31, 5173. (b) Hashimoto, S.; Watanabe, N.; Sato, T.; Shiro, M.; Ikegami, S. Tetrahedron Lett. 1993, 34, 5109. (c) Hashimoto, S.-I.; Watanabe, N.; Ikegami, S. Synlett 1994, 353. (d) Watanabe, N.; Anada, M.; Hashimoto, S.; Ikegami, S. Synlett. 1994, 1031.

27. Watanabe, N.; Ogawa, T.; Ohtake, Y.; Ikegami, S.; Hashimoto, S. Synlett 1996, 85. 
28. Davies, H. L. M.; Bruzinski, P. R.; Lake, D. H.; Kong, N.; Fall, M. J. J. Am. Chem. Soc. 1996, 118, 6897.

29. D'Augustin, M. DEA Thesis, University of Geneva, 2002.

30. Ferri, M. Diploma Thesis, University of Geneva, 2002.

31. Davies, H. M. L.; Cantrell, W. R.; Romines, K. R.; Baum, S. S. Org. Synth. 1992, 70, 93.

32. (a) Lee, R. R.; Suk, J. Y.; Kim, B. S. Tetrahedron Lett. 1999, 40, 6603. (b) Taber, D. F.; Ruckle, Jr. R. E. J. Org. Chem. 1986, 51, 4077.

33. Schank, K.; Lick, C. Synthesis 1983, 392.

34. Arnett, E. M.; Harrelson, J. A.; J. Am. Chem. Soc. 1987, 109, 809.

35. Neilands, O. Y.; Neiman, D. E. J. Org. Chem. USSR (English translation) 1970, 6, 2522. 